\title{
NATURAL GAS METERING AND ITS ACCURACY IN THE SMART GAS SUPPLY SYSTEMS
}

\author{
J. Savickis', L. Zemite ${ }^{2 *}$ I. Bode ${ }^{2}$, L. Jansons² \\ 'ITERA Latvija \\ 50 Skanstes Str., Riga, LV-1013, LATVIA \\ ${ }^{2}$ Riga Technical University, \\ Faculty of Power and Electrical Engineering, \\ Institute of Power Engineering \\ 12-1 Azenes Str., Riga, LV-1048, LATVIA \\ *e-mail: laila.zemite@rtu.Iv
}

The successful implementation of smart metering in the European Union (hereinafter EU) depends on criteria that are mostly determined by the Member States themselves. These criteria cover the regulatory framework and legislation necessary for the establishment and functioning of the smart metering system, the fulfilment of technical and commercial conditions, as well as the security of data collection, archiving and use. The introduction of the smart metering in different Member States has started at different times. In Latvia, its reference point was 2004, when the goal was set to maximise the use of telemetry in the natural gas metering. Currently, in the Latvian natural gas distribution system about $85 \%$ of all consumption data are automatically processed.

One of the most important components of the smart natural gas metering is natural gas commercial metering devices (hereinafter - smart meters). They differ in both the principle and type of operation. Depending on the technology used, the metering range changes, and thus the accuracy of the measurements.

The article addresses some issues of further successful implementation of smart metering in the Latvian natural gas sector, as well as the measurement accuracy for smart natural gas meters.

Keywords: Consumption data, distribution system, measurement accuracy, natural gas, natural gas flow, smart natural gas meters. 


\section{INTRODUCTION}

The natural gas smart metering cannot be implemented without a proper technical infrastructure, where one of the most important elements is smart natural gas meters themselves. They are rather different in both principle of operation and technological design. Depending on the technology used, the metering range and thus the accuracy of the measurements may differ.

By the end of 2020, the EU countries are expected to invest around 45 billion euro (hereinafter - EUR) in installation of around 45 million smart natural gas meters and almost 200 million smart electricity meters. At the same time, it is estimated that around $40 \%$ of the natural gas consumers and $75 \%$ of electricity consumers in the EU will be using smart electricity and gas metering devices in their household, businesses or public buildings. In most EU Member States, full replacement of mechanical electricity meters has already been implemented or is planned for the nearest future (3-5 years), but implementation of the smart natural gas metering in all segments of consumption is expected in just a few countries, for example, Italy and Finland [1].

Estimated costs of smart gas meters vary slightly across the EU as well, but on average the installation of such a device costs around 200-250 EUR per user and saves a total of 160 and 309 EUR, respectively, in the natural gas and electricity sectors.
In terms of energy saving, smart metering can help to save up to $3 \%$ of energy, which other would be wasted [2].

When the smart natural gas metering system is installed, the basic distribution costs consist of:

- one-time capital costs (including design, development and testing of the system);

- operating costs (including operation of the system and provision of data transmission, for example, with the usage of a SIM card and GSM communication).

Additionally, one-time capital and operating costs can be subdivided into the following expense categories:

- price of a smart meter;

- installation costs of a smart meter at the consumer's premises;

- communication system costs;

- IT system costs;

- $\quad$ system adaptation costs;

- maintenance and operating costs;

- data transmission costs;

- administrative expenses [3].

In Latvia, the Regulation of the Cabinet of Ministers No. 665 "Regulations on Metrological Requirements for Gas Consumption Meters and Volume Correctors" (hereinafter - Regulation No. 665) determines the minimum conditions for the natural gas flow, which apply to all types of natural gas meters, including the smart ones.

Table 1. The Natural Gas Flow Requirements

\begin{tabular}{|l|c|c|c|}
\hline Class & $\mathrm{Q}_{\max } / \mathrm{Q}_{\min }$ & $\mathrm{Q}_{\max } / \mathrm{Q}_{\mathrm{t}}$ & $\mathrm{Q}_{\mathrm{r}} / \mathrm{Q}_{\max }$ \\
\hline 1.5 & $\geq 150$ & $\geq 10$ & 1.2 \\
\hline 1.0 & $\geq 20$ & $\geq 5$ & 1.2 \\
\hline
\end{tabular}

According to Regulation No. 665, the term "minimum flow" $\left(Q_{\min }\right)$ means the flow at which the natural gas meter provides readings that meet the requirements for 
maximum permissible error (hereinafter MPE), while the term "maximum flow" $\left(\mathrm{Q}_{\max }\right)$ means the flow, at which the natural gas meter provides readings that meet the requirements for the MPE. The term "transient flow" $\left(Q_{t}\right)$ is also used to refer to a flow between the maximum and minimum flow and at which the flow range is divided into two zones: the upper and the lower. Each zone has its own MPE. Additionally, the term "congestion flow" $\left(\mathrm{Q}_{\mathrm{r}}\right)$ is applied to the highest flow at which the natural gas meter operates satisfactorily [4].

Regulation No. 665 also determines that MPE for the natural gas meters depends on their accuracy class. If a natural gas meter is intended to be used in the individual consumption sector, Class 1.5 shall be used for measurements, but if the $\mathrm{Q}_{\max / \mathrm{Qmin}}$ ratio is equal to or greater than 150 , Class 1.0 shall be used.

Table 2. Maximum Permissible Error Depending on the Accuracy Class of a Smart Gas Meter

\begin{tabular}{|l|c|c|}
\hline Class & 1.5 & 1.0 \\
\hline $\mathrm{Q}_{\min } \leq \mathrm{Q}<\mathrm{Q}_{\mathrm{t}}$ & $3 \%$ & $2 \%$ \\
\hline $\mathrm{Q}_{\mathrm{t}} \leq \mathrm{Q} \leq \mathrm{Q}_{\max }$ & $1.5 \%$ & $1 \%$ \\
\hline
\end{tabular}

Figure 1 shows that different minimum and maximum flow measurement limits are allowed for different natural gas meters (including smart metering devices), and these limits are overlapping. In addition, there are other criteria that affect the accuracy of the natural gas metering (pressure losses, natural gas flow fluctuations, lower flow limits etc.) [4].

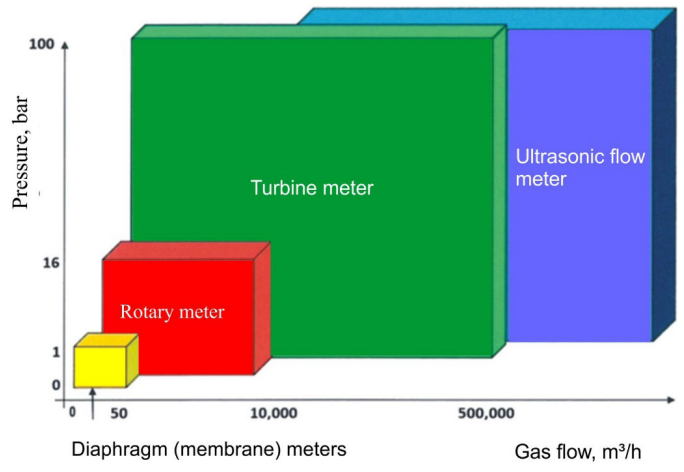

Fig. 1. Range of use of different natural gas meters.

In Latvia, the duration of the inspection period of the natural gas meters is set to be reasonable (5 years) and it protects the interests of the consumers; however, due to possible metering errors, the natural gas losses may increase. According to Paragraphs 26 and 27 of Decision No. 1/12 of the Council of the Public Utilities Commission of 6 August 2020 "Methodology for Calculating Natural Gas Distribution System Service Tariffs", distribution system operation costs are calculated according to a formula that includes technological process provision and natural gas loss costs, as well as the forecasted natural gas consumption for technological needs. These additional requirements oblige the natural gas distribution system operator (hereinafter - SSO) to assess the future usefulness of the older diaphragm (membrane) natural gas meters in the household sector [5]. At the same time, the necessity of control measurements in apartment buildings should be evaluated in order to determine the difference between the actual consumption numbers and those declared by individual consumers. 


\section{CHARACTERISTICS OF SMART METERING AND USE OF DIFFERENT TYPES OF NATURAL GAS METERS}

The introduction of smart metering in the EU Member States has started at different times. In comparison to smart electricity metering, the deployment of smart natural gas meters was and still is much slower. Although benefits of the smart metering system in the natural gas sector are obvious: it not only contributes to more efficient energy use, but also significantly optimises the management of the natural gas supply system and collection, analysis and archiving of data [6].

The smart meter communication system for data exchange consists of the following elements:

- a smart meter that performs the function of data registration and transmission;

- a data collector that receives and sends information from / to all meters connected to the system and installed in a particular area;

- communication systems (GSM, GPRS, etc.);

- information management systems [3].

Article 9 (2) of Directive 2012/27/EU provides that, when EU Member States implement smart metering and smart meters for natural gas and/or electricity consumption, in accordance with Directives 2009/72 / EC and 2009/73 / EC, they shall:

- ensure that the metering systems provide to final customers information on actual time of use and that the objectives of energy efficiency and benefits for final customers are fully taken into account when establishing the minimum functionalities of the meters and the obligations imposed on market participants;

- ensure the security of the smart meters and data communication, and the privacy of final customers, in compliance with relevant Union data protection and privacy legislation;

- require that appropriate advice and information be given to customers at the time of installation of smart meters, in particular about their full potential with regard to meter reading management and the monitoring of energy consumption [7].

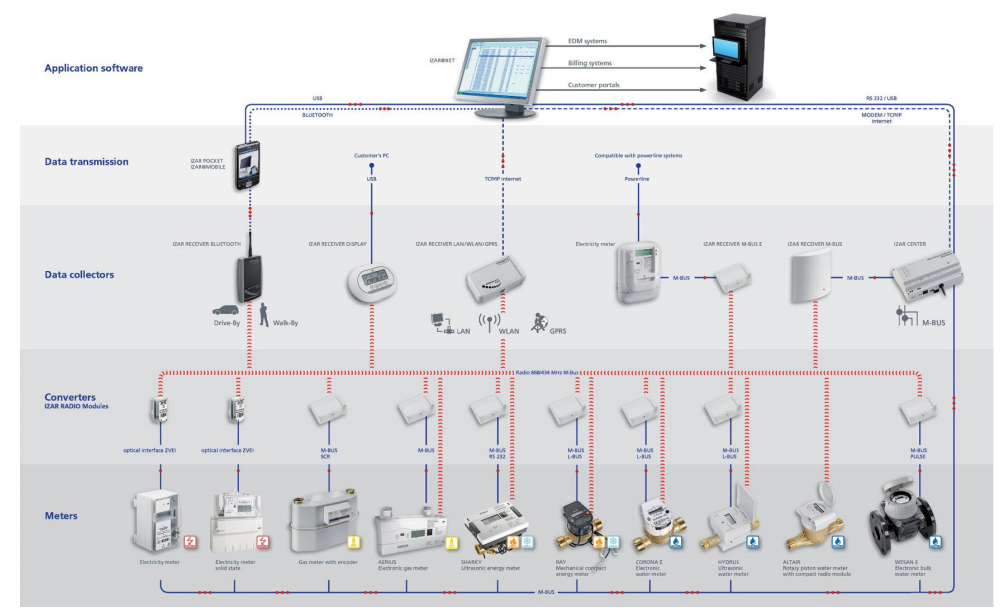

Fig. 2. The principal scheme of smart metering system (smart meters, convertors, data collectors, data transmitters, and data processing software). 
In absence of strict requirements for the choice of technical equipment and software, there is a situation where four data reading systems with different makeup and functionality coexist in the EU Member States, which at some extent hinders effective, comprehensive development of the smart natural gas metering. There are also no requirements set for external power supply to smart metering devices in high gas consumption facilities, where big amounts of data need to be read and transmitted several times a day.

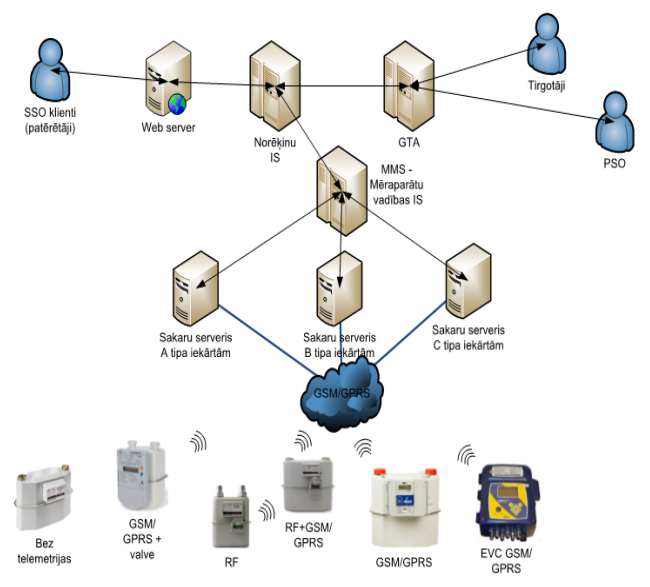

Fig. 3. Principle scheme of the natural gas smart metering system, JSC "Gaso".

For Latvia, a reference point for smart gas metering was 2004, when the goal was set to maximise the use of telemetry in the natural gas sector. Currently, in the Latvian natural gas distribution system about $85 \%$ of all consumption data are automatically processed. Data transmission is carried out via GSM communication system by inserting a SIM card into the data transmission device. Around 3,100 pressure and temperature correctors have been installed in the Latvian natural gas supply system, of which 510 are equipped with telemetry. However, according to technical and functional parameters, uniform requirements for the smart meters for the natural gas in Lat- via have not been determined yet. However, Section 16, Paragraph four of the Energy Efficiency Law (hereafter - EEL) allows the system operator, taking into account the needs and potential benefits of the energy consumers, to determine the minimum functions of a smart commercial metering device, including the possibility to obtain information on actual energy consumption in a specific period of time.

The EEL also stipulates that the system operator, when installing a smart commercial metering device, must provide energy consumers with information on the possibilities of the meter management and energy consumption monitoring [8]. The requirements for the protection of personal data in the EU derive from Regulation (EU) 2016/679 of the European Parliament and of the Council of 27 April 2016 on the protection of natural persons with regard to the processing of personal data and on the free movement of such data, and repealing Directive 95/46/EC (General Data Protection Regulation), which Latvia had enforced by the Personal Data Processing Law. The law, inter alia, provides that SSOs, as data controllers or processors, must also guarantee data security of the smart metering system and energy consumers [9].

Diaphragm (membrane) natural gas meters, which can also be equipped with a data transmission module, are mostly used for a low natural gas flow. In cases where natural gas has to be supplied to a small industrial enterprise or merchant, rotary natural gas meters are preferred. Turbine gas meters are designed to supply natural gas to industrial consumers at a massive, steady flow regime. However, under non-uniform load conditions, turbine meters generate metering errors [10]. Ideally, turbine meters should operate under stable and constant conditions of the natural gas flow in order to avoid pulsations and thus metering inac- 
curacies. If the flow of natural gas changes or is stopped altogether, the mechanism will continue to rotate for some time; thus, the metering inaccuracies are almost inevitable [11]. The effect of flow disturbances on the readings of the natural gas meter shall not exceed $1 / 3$ of the maximum permissible error of metering instrument of a particular type and technological design.

Diaphragm natural gas meters are used in Latvia up to G25 level, because other types of the natural gas meters with a higher performance rate have rather large dimensions and lower accuracy. For example, at times of pulsation of turbine natural gas meters, the inertia of the turbine wheel and subsequent metering error may occur during on and off mode [12].

Ultrasonic and microthermal natural

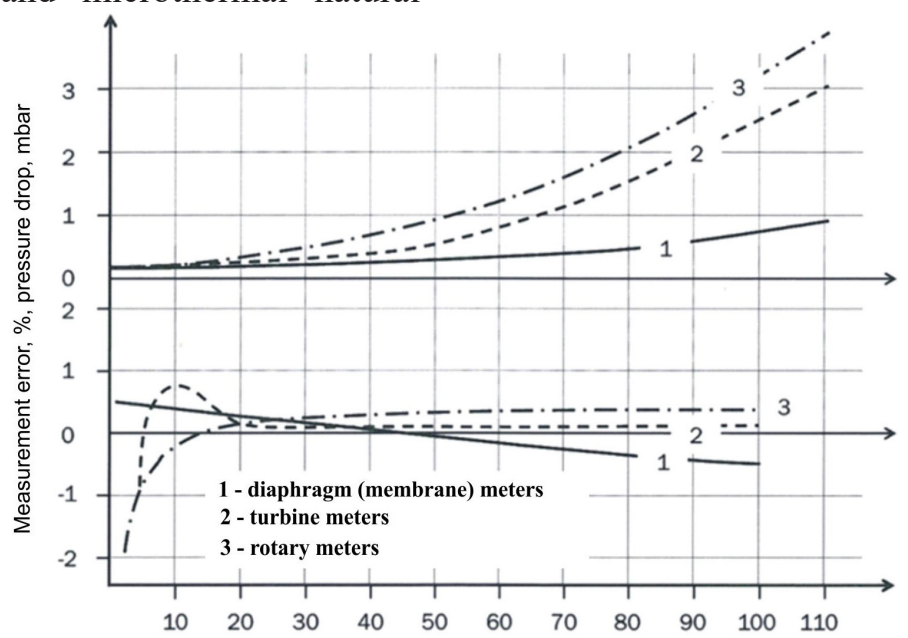

Fig. 4. Influence of pressure changes on metering errors of different type natural gas meters.

Studies have been carried out over the past decade in several European countries, including Italy, to determine the longevity of different types of the natural gas meters and variations in metering errors as the equipment ages and the degree of physical wear and tear increases.

One Italian study surveyed 402 diaphragm natural gas meters with different service life (up to 50 years old). As a result, it was concluded that the observed tendency gas meters are an alternative to diaphragm, rotary and turbine natural gas meters. They are used when exclusively high measurement accuracy is required [13]. Microthermal meters can keep an accurate metering rate even at very low initial flows. If correct functioning of diaphragm natural gas meters largely depends on the temperature and pressure, which can be seriously jeopardized without temperature and pressure correction, microthermal meters adjust metering specification to these factors automatically [14]. In contrary to diaphragm natural gas meters, the membranes of which may lose their elasticity over time, microthermal meters do not have moving parts that are subject to wear and tear and can affect the accuracy of metering. 


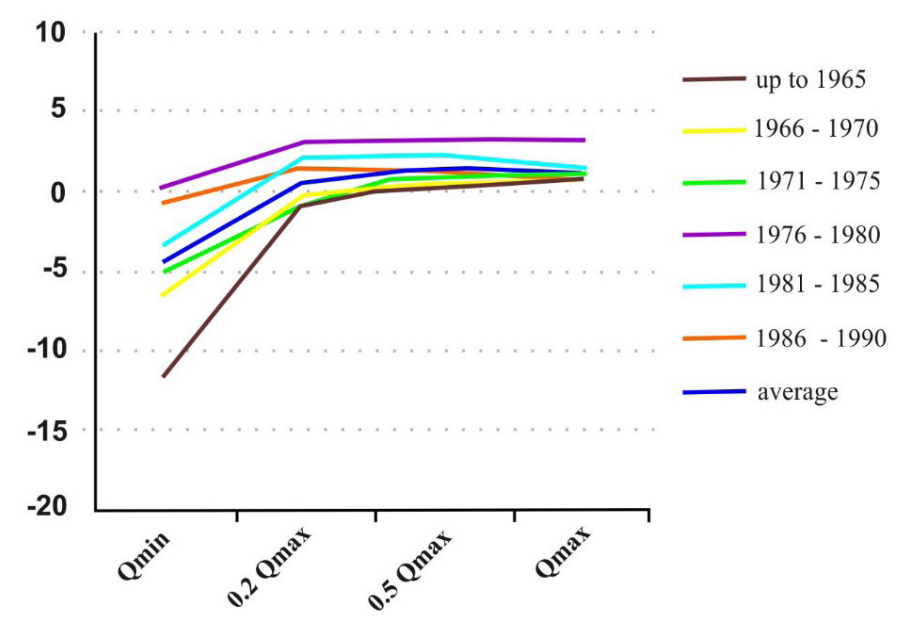

Fig. 5. The observed tendency of the natural gas metering deviation.

Another study, also from Italy, analysed dynamics of metering errors for diaphragm natural gas meters manufactured between 1965 and 2006. As a result of this study, it was confirmed that minimal metering errors appeared at a minimum flow, with a tendency to increase with age.

When comparing several types of smart natural gas meters according to the technical parameters of flow measurement, the best technical parameters refer to individual ultrasonic and microthermal meters with a wider measuring range, as well as the pos- sibility to perform satisfactory at low minimum flows. However, external factors, such as installation location (outdoor or indoor), temperature, volumes of the gas flows, and other conditions may affect the technical parameters (operating temperature, battery life, etc.) or materials of the metering devices. Plastic parts of the meters wear out sooner at high flow volumes and pressure than metallic ones; thus, metallic parts can be manipulated externally - for instance, affected by magnets.

\section{METERING ERRORS AND THEIR CORRECTION}

The natural gas meter measures natural gas flow parameters under ideal conditions, but more precisely the amount of natural gas can only be determined at a certain temperature and pressure regime.

A temperature and pressure corrector that adjusts the metering data according to standard conditions (conditions at a natural gas pressure of $101,325 \mathrm{kPa}$ and a temperature of $20^{\circ} \mathrm{C}$ ) can be used in three ways:

- determining the volume under certain standard conditions according to Charles' law;
- according to the ideal gas law, determining the volume at a certain standard temperature and pressure;

- on the basis of known real natural gas parameters, determining the volume under standard conditions.

The maximum permissible error of the natural gas meter increases as the conversion complexity grows, given that in the former case the operation is the simplest, and in the latter - the most complex [16]. Thus, a correction factor is determined that adjusts the 
listed natural gas volume. For example, if at a temperature of $18^{\circ} \mathrm{C}$ the correction coefficient is 0.99308 and the measured volume of the natural gas is $1000 \mathrm{~m}^{3}$, then the calculated volume will be $993.08 \mathrm{~nm}^{3}$. On the other hand, as the temperature increases to $22{ }^{\circ} \mathrm{C}$, the coefficient increases to 1.00692 and, accordingly, for the same measured volume, the calculated volume of the natural gas comes up to $1006.92 \mathrm{~nm}^{3}$. Thus, a temperature change of $1^{\circ} \mathrm{C}$ affects the measured volume by $0.346 \%$ [17].

Meters with a built-in temperature compensating element would significantly reduce the possibility of metering errors. Such meters should also be used indoors, as the temperature and pressure at the location of the natural gas meter often differ from the standard temperature. For example, pressure, unlike standard conditions, can cause a meter mismatch of up to $1.97 \%$ [17]. Problems with installation depth of the temperature sensor shell also might occur, and at a consumption of almost 8000 $\mathrm{nm}^{3}$, the difference between the installation depth of the shell can cause losses of more than 500 EUR [17]. However, choosing a new ultrasonic or microthermal natural gas meter with the integrated communication module, temperature corrector and shut-off valve solves the problem of possible shell installation depth manipulations.

\section{SMART METER USE AND ITS ADVANTAGES}

The benefits of smart natural gas meters can be divided into several categories:

1. based on the technical parameters of equipment:

- more accurate, dynamic and safe natural gas metering;

- efficient management of a meter by receiving a system alarm signal (temperature, manipulation, battery, air in a pipe);

- remote reading of a meter;

- possibility to choose different communication solutions for data transfer (mobile, radio, optical cable or wireless technologies).

2. based on the efficient use in the natural gas systems:

- remote automatic reading of data saves the system operator's resources by reducing the need for physical inspection (reading, interruptions of the natural gas supply, verification of the physical condition of the equipment, etc.);
- efficient and quick identification of the natural gas leaks or other technical problems in the gas pipelines [18];

- reduction of unlawful natural gas use, with is easily identifiable by examining atypical loads, which do not correspond to the historical or most recent consumption profiles;

- by fulfilling the obligations specified in Regulation of the Cabinet of Ministers No. 78 "Regulations on Trade and Use of Natural Gas" (hereinafter - Regulation No. 78), it is possible to improve system balancing forecast with more and more accurate consumption data [19];

- improved customer service (applications, consumption data analysis, immediate consumption control and data reading);

- the received data allows the operator to segment and profile customers according to their consumption specifications; 
- possibility to remotely and quickly cut off the supply of natural gas without entering the property. According to Regulation No. 78, DSO is entitled to suspend the supply of the natural gas in cases of non-settlement or termination of the supply agreement;

- more convenient system management in case of major accident, crisis or state emergency, including fulfilment of the obligation of the system operator to restrict gas supply specified in Regulation of the Cabinet of Ministers No. 312 "Procedures for the Supply of Energy Users and the Sale of Fuel during the Energy Crisis and in the
Event of a State Emergency". Availability of more accurate data about the system allows for more accurate calculation of system losses in the above-mentioned cases, too [20];

- installation of the smart metering system at gas metering checkpoints.

3. based on energy efficiency and comfort of the natural gas consumers:

- convenient and accurate information about consumed natural gas, which can be obtained electronically;

- permanent information on natural gas consumption allows consumers to re-examine their consumption habits and adjust them to save financial and energy resources.

\section{CONCLUSIONS}

Smart natural gas metering meets requirements for fast and accurate collection, analysis and archiving of the natural gas consumption data, as well as provides opportunities for SSOs to more effective evaluation and planning of the natural gas supply system development in various regions of Latvia and other EU countries. It also may contribute to the achievement of energy efficiency and system security targets [21]-[23], which ensure sustainable economic development and prevention of further climate change.

More attention should be paid to studies on usefulness of wider implementation of natural gas metering in Latvia. It is necessary to evaluate benefits that can be archived from different viewpoints, such as technical, economic, operational, administration, etc. Currently, neither in Latvia, nor in the EU as a whole, unified technical requirements for smart natural gas meters and guidelines for their operation have been developed and legally established, which to some extent hinders the overall pace of effective energy consumption. It is necessary to re-evaluate the link between smart metering of natural gas and variations in legal ownership of these meters in Latvia. It should be done to reduce bureaucratic and legal obstacles that prevent full implementation and use of smart natural gas metering.

Different types of the natural gas meters (including those that can be equipped with telemetry) have different minimum and maximum flow limits, and these limits overlap. In addition, accuracy of natural gas measuring may be affected by other factors, such as pressure losses and natural gas flow fluctuations.

When comparing several types of smart meters according to the technical parameters of flow measurement, the best results are demonstrated by individual ultrasonic and microthermal natural gas meters with a wider measuring range, as well as the possi- 
bility to enhance very low minimum flows.

Meters with a built-in temperature compensating element would significantly reduce the possibility of metering errors. Such meters should also be used indoors, as the temperature and pressure at the location of the natural gas meter often differ from the standard temperature.

The use of new ultrasonic or microthermal smart meters with the integrated communication module, temperature corrector and shut-off valve solves the problem of shell installation depth manipulations.

In Latvia, the duration of the meter inspection period is set to be reasonable and it protects the interests of consumers; however, due to metering errors, natural gas losses may increase between verification events. To avoid this situation in the individual consumption sector, it would be desirable to assess:

- future replacement of older diaphragm natural gas meters;

- opportunity to carry out more extensive inventory of the natural gas use in apartment buildings in order to pinpoint the difference between the actual and declared natural gas consumption;

- opportunity to replace multiple single unit (flat) natural gas meters with one single smart meter in apartment buildings as it is done in several EU countries, for example, Finland.

\section{ACKNOWLEDGEMENTS}

The research has been supported by the National Research Programme, project "Trends, Challenges and Solutions of Lat- vian Gas Infrastructure Development" (LAGAS) (No. VPP-EM-INFRA-2018/10003).

\section{REFERENCES}

1. Bianchini, A., Saccani, C., Guzzini, A., \& Pellegrini, M. (2018). Gas Smart Metering in Italy: State of the Art and Analysis of Potentials and Technical Issues. [online]. [accessed 10 July 2020]. Available at https://www.researchgate.net/ publication/330260200_Gas_smart metering_in_Italy_state_of_the_art_and analysis_of_potentials_and_technical_ issues

2. Report from the Commission. Benchmarking Smart Metering Deployment in the EU-27 with a Focus on Electricity/* COM/ 2014/0356 final */ [online]. [accessed 1 September 2020]. Available at https://eurlex.europa.eu/legal-content/GA/TXT/?uri= COM\%3A2014\%3A356\%3AFIN
3. Eurogas Distribution Committee Report on Smart Gas Metering. (2010). [online]. [accessed 8 June 2020]. Available at http://www.eurogas.org/policy-areas/listofdocuments/?tx_ttnews $\% 5 \mathrm{Bcat} \% 5 \mathrm{D}$ $=9 \&$ tx ttnews $\% 5$ Bpointer $\% 5 \mathrm{D}=2 \& \mathrm{cHash}$ $=700 \mathrm{~b} 097 \mathrm{~d} 2 \mathrm{f} 12 \mathrm{c} 3915436 \mathrm{c} 9 \mathrm{ec} 841 \mathrm{ed} 8 \mathrm{e} 2$

4. Ministru kabineta noteikumi Nr. 665 "Noteikumi par metrologiskajām prasībām gāzes patēriņa skaitītājiem un tilpuma korektoriem". [online]. [accessed 12 September 2020]. Available at: https:// likumi.lv/ta/id/142374-noteikumi-parmetrologiskajam-prasibam-gazes-paterinaskaititajiem-un-tilpuma-korektoriem

5. Sabiedrisko pakalpojumu regulēšanas komisijas padomes lēmums Nr. 1/12 
"Dabasgāzes sadales sistēmas pakalpojuma tarifu aprēķināšanas metodika". [online]. [accessed 17 August 2020]. Available at https://likumi.lv/ta/id/316609dabasgazes-sadales-sistemas-pakalpojumatarifu-aprekinasanas-metodika

6. Toratti, J. (2020). Appraising the economics of smart meters: Costs and benefits. London: Routledge.

7. Directive 2012/27/EU of the European Parliament and of the Council of 25 October 2012 on energy efficiency, amending Directives 2009/125/EC and 2010/30/EU and repealing Directives 2004/8/EC and 2006/32/EC. [online]. [accessed 9 August 2020]. Available at https://eur-lex.europa.eu/legal-content/EN/ TXT/?uri=celex\%3A32012L0027

8. Energoefektivitātes likums (2016). [online]. [accessed 11 August 2020]. Available at https://likumi.lv/doc. php?id=280932

9. Fizisko personu datu apstrādes likums [online]. [accessed 6 June 2020]. Available at https://likumi.lv/ta/id/300099fizisko-personu-datu-apstrades-likums

10. Stoltenkampa, P.W., Bergervoetb, J.T.M., Willemsa, J.F.H., van Uitterta, F.M.R., \& Hirschberga, A. (2008). Response of Turbine Flow Meters to Acoustic Perturbations. Journal of Sound and Vibration, 258-278.

11. Cascetta, F., \& Rotondo, G. (2015). Effects of Intermittent Flows on Turbine Gas Meters Accuracy. Second University of Naples, Italy Measurement, 69, 280286.

12. Platais, I., \& Graudiņš, P. (2008). Gāzapgāde. 1.dalı. Ogl̦ūdenražu deggāzes, to ìpašības, metrologija un sadedzināšana. Rīga: RTU izdevniecība. 63. lpp.

13. Homann, K., Reimert, R., \& Bernhard, K. (2013). The gas engineer's dictionary. Supply infrastructure from $A$ to $Z$. Germany: DIV Deutscher Industrieverlag GmbH. 274 p.

14. AERIUS. (2018). The Intelligent Form of Gas Metering. [online]. [accessed 6 March 2020]. Available at http://www. diehl.com/fileadmin//diehl-metering/dlc/ Gas/AERIUS_Folder_EN.pdf

15. Ficco, G. (2014). Metrological Performance of Diaphragm Gas Meteres in Distribution Networks - Flow Measurement and Instrumentation. Flow Measurement and Instrumentation, 37, 65-72.

16. Salkazanovs, J. (2015). Dabasgāzes uzskaites datu attālināta nolasī̌̌ana. Mağistra darbs. Rīga: Rīgas Tehniskā universitāte.

17. Bērzājs, M. (2017). Dabasgāzes uzskaites optimizēšanas daudzdzīvokļu ēkās. Maǵistra darbs. Rīga: Rīgas Tehniskā universitāte. 44 lpp.

18. Zemite, L., Kutjuns, A., Bode, I., Kunickis, M., \& Zeltins, N. (2018). Risk Treatment and System Recovery Analysis of Gas System of Gas and Electricity Network of Latvia. Latvian Journal of Physics and Technical Sciences, 55 (5), 3-14. DOI: 10.2478/lpts-2018-0031.

19. Ministru kabineta noteikumi Nr. 78 "Dabasgāzes tirdzniecības un lietošanas noteikumi”. [online]. [accessed 1 September 2020]. Available at https:// likumi.lv/ta/id/289031-dabasgazestirdzniecibas-un-lietosanas-noteikumi

20. Ministru kabineta noteikumi Nr. 312 "Enerǵijas lietotāju apgādes un kurināmā pārdošanas kārtība izsludinātas enerḡêtiskās krīzes laikā un valsts apdraudējuma gadījumā". [online]. [accessed 5 September 2020]. Available at https://likumi.lv/ta/id/229557-energijaslietotaju-apgades-un-kurinama-pardosanaskartiba-izsludinatas-energetiskas-krizeslaika-un-valsts-apdraudejuma-gadijuma

21. Zemite, L., Kutjuns, A., Bode, I., Kunickis, M., \& Zeltins, N. (2018). Consistency Analysis and Data Consultation of Gas System of Gas-Electricity Network of Latvia. Latvian Journal of Physics and Technical Sciences, 55 (1), 22-34. DOI: 10.2478/lpts-2018-0003. 
22. Koposovs, A., Bode, I., Zemite, L., Dzelzitis, E., Odineca, T., Ansone, A., Selickis, A., ... \& Jasevics, A. (2019). Optimization of the Selection Method for Reconstruction of Outworn Gas Distribution Pipeline. Latvian Journal of Physics and Technical Sciences, 56 (5), 33-44. DOI: 10.2478/lpts-2019-0029.
23. Savickis, J., Zemite, L., Zeltins, N., Bode, I., \& Jansons, L. (2020). Natural Gas and Biomethane in the European Road Transport: The Latvian Perspective. Latvian Journal of Physics and Technical Sciences, 57 (3), 57-72. DOI: 10.2478/ lpts-2020-0016. 